\title{
IMPLIKASI PELATIHAN MASSAGE TERHADAP KETERAMPILAN HIDUP TUNANETRA DI MASA PANDEMI COVID-19
}

\author{
Sri Mulyani \\ Program Studi Pendidikan Masyarakat IKIP Siliwangi, Cimahi, Jawa Barat, Indonesia \\ srim260699.sm@student.ikipsiliwangi.ac.id
}

Received: January, 2021; Accepted: February, 2020

\begin{abstract}
This research is motivated by visual impairment, blind people do not hesitate to have massage skills. This study aims to change the stigma that exists in society, that blind people can only beg and busk can be changed with the existence of massage training that provides life skills to make a living. The method used is a qualitative approach using descriptive methods through interview techniques. The results of this research indicate that massage training is one of the alternatives in shaping the character of the blind to become independent and skilled. The discussion suggests massage training, which implementation is hampered by the Covid-19 pandemic, but does not deter the hall from stopping all training activities, still trying with various media to convey material and practice. Even though the participants had difficulties in the training process, it did not discourage them from having life skills. The conclusion of this research is that life skills are important for every human being, including age and position, massage training is one proof that the presence of training centers can have a positive impact on visual impairment.
\end{abstract}

Keywords: Massage Training, Life Skills, Covid-19 Pandemic

\begin{abstract}
Abstrak
Penelitian ini dilatar belakangi oleh keterbatasan penglihatan, tunanetra tidak segan untuk memiliki keterampilan massage. Penelitian ini bertujuan agar stigma yang ada di masyarakat, bahwa tunanetra hanya bisa mengemis dan mengamen dapat dirubah dengan adanya pelatihan massage yang memberikan keterampilan hidup untuk dijadikan mata pencaharian. Metode yang digunakan adalah pendekatan kualitatif dengan menggunakan metode deskriptif melalui teknik wawancara. Hasil dari penelitian ini menunjukkan bahwa pelatihan massage sebagai salah satu alternative dalam membentuk karakter tunanetra menjadi mandiri dan terampil. Pembahasan mengemukakan pelatihan massage yang mana pelaksanaanya terhambat oleh pandemic covid-19, akan tetapi tidak menyurutkan balai untuk menghentikan semua kegiatan pelatihan, tetap berupaya dengan berbagai media untuk menyampaikan materi serta praktek. Walaupun peserta kesulitan dalam proses pelatihan tidak mematahkan semangatnya untuk memiliki keterampilan hidup. Kesimpulan dari penelitian ini yaitu keterampilan hidup merupakan hal yang penting bagi setiap manusia tidak terkecuali usia maupun jabatan, pelatihan massage menjadi salah satu bukti bahwa dengan adanya balai memberikan pelatihan mampu memberikan dampak positif terhadap para tunanetra.
\end{abstract}

Kata Kunci: Pelatihan Massage, Keterampilan Hidup, Pandemi Covid-19

How to Cite: Mulyani, S. (2021). Implikasi Pelatihan Massage Terhadap Keterampilan Hidup Tunanetra di Masa Pandemi Covid-19. Comm-Edu (Community Education Journal) 4 (1), $14-22$. 


\section{PENDAHULUAN}

Hilangnya daya penglihatan seseorang akan berimplikasi terhadap banyak hal. Istilah seseorang yang hilangnya daya penglihatan disebut tunanetra. Anak tunanetra merupakan salah satu populasi dari anak berkebutuhan khusus, yang karena satu hal mengalami hambatan dalam penglihatannya. Seorang anak tunanetra, indera penglihatan yang tidak berfungsi kedua-duanya yang di pergunakan dikehidupan sehari-hari sebagai penerima informasi sepeti halnya orang awas (Somantri, 2007).

Anak tunanetra dibagi menjadi 2 kategori yaitu buta total dan kerusakan sebagian (low vision), seorang anak yang dikatakan buta total yaitu anak yang tidak bisa melihat sama sekali karena tidak adanya cahaya yang dapat masuk ke dalam matanya. Sedangkan seorang anak yang dikatakan low vision jika anak tersebut masih bisa melihat walaupun sebagian karena hanya sedikit cahaya yang dapat masuk ke dalam matanya.

Berdasarkan data Sukses Sensus Nasional (Susenas) tahun 2012 sebagaimana dikutip dalam Kemenkes (2014) bahwa penduduk indonesia yang menyandang disabilitas sebesar 2,45\% dari jumlah penduduk indonesia dengan persentase terbesarnya yaitu disabilitas mengenai kesulitan dalam melihat atau disebut juga tunanetra. Sedangkan berdasarkan survei Penduduk Antar Sensus BPS pada tahun 2015 di Indonesia menujukkan jumlah penyandang disabilitas sebanyak 21,5 Juta jiwa. Pada tahun 2016, data dari Sakernas menunjukkan bawa jumlah penyandang disabilitas untuk usia diatas 15 tahun adalah 12,5\% (sekitar 22,8 juta jiwa) (Mustofa, 2019).

Dari banyaknya jumlah penyandang disabilitas, seseorang yang memiliki hambatan dalam penglihatan atau disebut tunanetra merupakan bagian dari masyarakat negara dimana tugas ini merupakan tanggung jawab bersama antara keluarga, pemerintah, LSM, kalangan swasta dan masyarakat pada umumnya. memerlukan beberapa bimbingan dan pelatihan.

Tunanetra setelah lulus dari sekolah formal dapat melanjutkan ke perguruan tinggi atau memilih untuk mengikuti berbagai macam pelatihan yang di sediakan untuk tunanetra. Pelatihan ini dimana setelah selesai dapat langsung terjun ke dunia kerja, pelatihan memiliki ragam, tergantung minat dari masing-masing tunanetra itu sendiri. Pelatihan yaitu suatu proses belajar untuk memperoleh dan meningkatan keterampilan di luar system yang berlaku, dalam waktu yang relative singkat dengan menggunakan metode yang lebih menggunakan praktik daripada teori. Menurut (Widodo, 2015), pelatihan merupakan serangkaian aktivitas yang dilakukan individu yang memiliki tujuannya untuk dirinya sendiri untuk meningkatkan keahlian dan pengetahuan.

Dewasa ini, pelatihan yang sering terdengar dan diikuti oleh penyandang disabilitas netra yaitu pelatihan massage dan shiatsu. Namun dalam penelitian ini lebih difokuskan pada pelatihan massage di masa pandemic Covid-19. Dimana proses pelatihannya dilakukan secara daring. Kata massage berasal dari Bahasa Arab "Maas" yang berarti menyentuh atau meraba, Massage diambil dari Bahasa Francis. Dalam bahasa Indonesia disebut atau menggurut (lutut) (Nuraini, 2016). Massage sendiri mempunyai arti yaitu perawatan tubuh dengan menggunakan kedua tangan pada bagian telapak tangan maupun jari-jari tangan. Dengan massage dapat memberikan manfaat berupa relaksasi, mengurangu nyeri, memperbaiki organ tubuh dan memelihara kebugaran, dengan pelatihan massage ini diyakini peredarah darah akan semakin lancar badan semakin relaks, tubuh semakin bugar dan berpengaruh pada peningkatan kesehatan (Junaidi, et al., 2017). 
Pelatihan massage ini menjadikan salah satu keterampilan hidup yang akan dimiliki oleh penyandang disabilitas netra. Menurut WHO (1997) keterampilan hidup (life skills) adalah berbagai macam keterampilan atau kemampuan untuk dapat berdaptasi dan berperilaku positif, yang mampu memungkinkan seseorang menghadapi berbagai tuntutan dan tantangan di dalam kehidupan sehari-hari secara efektif. Memiliki keterampilan hidup merupakan hal yang sangat penting bagi semua orang termasuk tunanetra, namun tidak semua keterampilan hidup dapat dilakukan oleh tunanetra karena adanya keterbatasan dalam penglihatan, tetapi ada beberapa keterampilan hidup dapat dilakukan oleh tunanetra di antaranya: mengajar, massage maupun shiatsu, seniman, menulis dan sebagainya. Sehingga perlu diadakan pelatihan keterampilan hidup untuk tunanetra khususnya pelatihan massage yang dilaksanakannya di masa pandemic Covid-19, dimana pelatihan ini cenderung diminati oleh sebagian besar masyarakat.

\section{METODE}

Metode penelitian menggunakan pendekatan kualitatif dengan metode deskriptif. Metode ini dipilih karena data yang dikumpulkan dalam penelitian ini berupa kata-kata. Penelitian ini juga bermaksud untuk memahami, mengungkap dan menjelaskan berbagai gambaran atas beberapa fenomena-fenomena yang ada di lapangan dan kemudian dirangkum menjadi kesimpulan deskriptif berdasarkan data dari hasil penelitian yang dikumpulkan sendiri oleh peneliti (Gitardiana \& Namawi, 2017). Salah satu ciri dari penelitian kualitatif adalah deskriptif, data yang dikumpulkan adalah berupa uraian yang dijabarkan dengan kata-kata yang menjadi kalimat dan paragraph (Azzahro \& Kurniadi, 2017).

Sedangkan instrument penelitian yang digunakan dalam penelitian ini sebagai berikut:

Pertama, studi dokumentasi adalah sebuah dokumen yang di dalamnya ada catatan peristiwa yang sudah berlalu. Dokumen bisa berbentuk tulisan, gambar atau karya-karya monumental dari seseorang, dokumen yang berbentuk tulisan misalnya catatan harian, sejarah kehidupan (life histories), ceritera, biografi, peraturan, kebijakan. Dokumen yang berbentuk gambar misalnya foto, gambar hidup, sketsa dan lain-lain (Sugiyono, 2018).

Kedua, wawancara adalah pertemuan dua orang untuk bertukar informasi dan ide melalui tanya jawab, sehingga dapat dikontruksikan makna dalam sebuah topik tertentu (Sugiyono, 2018).

Teknik analisis data di proses melalui reduksi data, penyajian data, menarik kesimpulan dan triangulasi sumber data. Objek penelitian pada saat pengumpulan data melalui wawancara dengan peserta pelatihan massage sejumlah 3 orang, 1 orang instruktur dan 1 pegawai di BRSPDSN Wyata Guna Jl. Pajajaran, Pasir Kaliki, Kecamatan Cicendo Kota Bandung, Jawa Barat.

\section{HASIL DAN PEMBAHASAN}

\section{Hasil}

\section{Pelaksanaan Pelatihan Massage di BRSPDSN Wyata Guna di masa Pandemi Covid-19}

Berdasarkan hasil wawancara kepada instruktur pelatihan massage di BRSPDSN Wyata Guna P. W, diperolehlah informasi bahwa pelatihan massage yang dilaksanakan di masa pandemic covid-19 intrukstur mengalami beberapa kesulitan dimana pelatihan massage 
sendiri seharusnya dilakukan dengan cara banyak praktek langsung daripada teori sedangkan dengan pandemic ini seorang instruktur harus lebih kreatif bahkan harus bisa mensiasati agar materi-materi itu bisa tersampaikan. Di masa pandemic ini yang seharusnya pelatihan dilakukan 6 bulan ada yang hanya satu bulan, dua bulan melakukan pelatihan setelah ini terkena pandemic covid-19. Akhirnya seorang instruktur mensiasati pelatihannya dengan cara melakukan teleconference baik melalui whatsapp, ataupun melalui zello atau bahkan memakai aplikasi zoom. Tetapi, pada pelaksanaannya peserta pelatihan kesulitannya dari data baik dari signal ataupun pada masa pandemic covid-19 pesertanya mengalami kesulitan dalam membeli kuota dan yang lain-lainnya. Sebagai instruktur harus memiliki terobosan untuk membuat keterangan atau penyampaian materi dengan melalui channel youtube. Nama channel youtubenya yaitu Teratif Tekno, dimana di channel youtube ini instruktur menjelaskan secara jelas. Jelas disini peserta didik bisa terus mengulang materi yang ada di dalam video, bahkan agar lebih efektif dalam segi kuota peserta didik bisa mengunduh terlebih dahulu videonya agar dapat diulang secara terus menerus. Sebagian besar tunanetra lebih tepat menggunakan metode pelaksanaan pelatihan dengan cara ini di masa pandemic covid-19, walaupun harus dibantu oleh anggota keluarganya, saudaranya untuk menunjukkan bagian mana dan titik-titik mana yang harus dipijat. Jika berbicara masalah pandemic covid19 semuanya serba susah dari mulai pelatihan massage ataupun pelatihan-pelatihan yang lainnya. Tetapi, sebagai instruktur harus bisa mensiasati supaya materi-materi bisa tersampaikan dan peserta pelatihan mencapai target yang telah ditentukan. Maksimal dalam pencapaiannya yang dari $100 \%$ saat $70 \%$ dianggap sudah layak, untuk test lebih cenderung banyak teori yang dilakukan melalui google forms, dan pada akhirnya semuanya dikerjakan menggunakan teknologi yang ada. Peserta pelatihan diwajibkan bisa mengisi google forms, dan harus mempunyai aplikasi-aplikasi yang menunjang dalam pembelajaran saat pelatihan. piagam penghargaan atau semacamnya untuk dirinya sendiri agar mereka bisa memenuhi keterampilan hidupnya dengan cara memijat.

Menurut peserta pelatihan $\mathrm{N}$, di masa pandemic covid-19 $\mathrm{N}$ dan teman-teman yang lain dipulangkan karena berbagai macam pertimbangan, karena takutnya ada yang terkena wabah covid-19. Di awal pandemic masih melakukan pelatihan setelah merebahnya pandemic covid-19, N pun pulang kerumahnya dan pembelajarannya dilakukan secara online. Tetapi, dari pembelajaran online tersebut ia tidak bisa mengikutinya setiap saat dikarenakan keterbatasan kuota dan sebagainya. Dengan adanya pembelajaran online dirasa kurang efektif karena pelatihan massage yang belajarnya berkenaan titik-titik urat saraf refleksi, karena penyandang disabilitas tidak melihat jadi harus dilakukan praktek langsung bukan secara daring atau sebagainya. Apa pun bentuknya itu menjadi salah satu cara agar peserta pelatihan tetap belajar walaupun berada dirumahnya masing-masing.

Sedangkan menurut peserta pelatihan B, sewaktu adanya pandemic covid-19 keluarlah surat edaran dari kementrian social yang menyatakan kepada seluruh jajaran pegawai balai untuk menganjurkan memulangkan peserta pelatihan, tetapi B tidak bergegas pulang dikarenakan B menggaris bawahi isi surat edaran tersebut yang mana di surat tersebut hanya menganjurkan bukan mengharuskan peserta pelatihan pulang, sehingga B memutuskan untuk melanjutkan untuk mengikuti pelatihan. Ia juga mencoba menyampaikan aspirasinya kepada balai dan 
balai meresponnya mempersilahkannya tetap melanjutkan pelatihan, karena aktivitas balai tetap berlangsung terlebih sebagian besar pegawai dan instruktur pelatihan tinggal dilingkungan komplek balai, sehingga anjuran-anjuran dari pemerintah untuk penanganan covid-19 dapat diterapkan. Kemudian pelatihan pun kembali berlangsung meskipun B harus melanjutkan pelatihannya sendirian tanpa adanya teman karena teman-temannya memilih untuk pulang. Dari situlah, B mendapatkan bonus pelatihan yaitu selain mengikuti pelatihan massage ia juga dapat mengikuti pelatihan shiatsu. Dimana untuk pelatihannya sendiri massage dilaksanakan 14 kali pertemuan dan shiatsu 10 kali pertemuan. Pada akhirnya selama 3 bulan mengikuti pelatihan di BRSPDSN Wyata Guna dapat memiliki keterampilan hidup massage dan shiatsu.

\section{Implikasi dari Pelatihan Massage terhadap Keterampilan Hidup Tunanetra di Masa Pandemi Covid-19}

Berdasarkan hasil wawancara dengan peserta pelatihan massage $\mathrm{N}$ dari adanya pelatihan ini sangat bermanfaat untuk membekali teman-teman tunanetra. Dengan keterampilan yang di dapat dari pelatihan massage di masa covid-19 membuat peserta pelatihan lebih mandiri, peserta pelatihan bisa bekerja sesuai dengan keahlian yang telah dimiliki bahkan sertifikat yang telah di dapatkan saat mengikuti pelatihan massage. Dengan keahlian tersebut mereka bisa bekerja berdampingan dengan masyarakat seperti biasa. Hasil dari pelatihan ini, jika peserta pelatihan bersungguh-sungguh dalam belajar hasilnya pun akan di dapatkan kedepannya. Bisa diimplikasikan dimasyarakat, bahkan dari pelatihan tersebut menjadikan keahlian yang telah didapatkan menjadikan mata pencaharian untuk tunanetra sendiri.

Sedangkan menurut peserta pelatihan B, setelah mengikuti pelatihan tersebut pada dasarnya B mengikuti pelatihan bukan karena tidak mempunyai pekerjaan tetapi ingin mengikuti pelatihan untuk menambah keterampilan hidupnya. Karena sebelum mengikuti pelatihan massage B sudah mempunyai usaha yang sudah dijalani, namun ia rasa usaha yang telah dijalani perlu dikembangkan dengan cara membuka usaha dibidang yang lain seperti terapis yang bertujuan agar usaha yang dijalani tidak terfokus pada satu bidang, kemudian B ingin membantu para tunanetra memberikan lapangan pekerjaan di bidang terapis, selain itu B ingin merubah paradigma tunanetra yang hanya bisa mengemis dan mengamen dijalanan, dan ingin merubah stigma masyarakat luas yang masih memandang sebelah mata bahwa tunanetra hanya bisa mengemis dan mengamen untuk memenuhi kebutuhan sehari-harinya, tidak bisa memenuhi kebutuhan hidupnya dari bidang lain. Berdasarkan alasan tersebut, sebelum ia memberikan lapangan pekerjaan dibidang terapis maka ia ingin mempelajari, memahami karena bila perumpamakan jika kita buka usaha rumah makan, lalu kita tidak memiliki keterampilan masak, hanya mengandalkan pada koki, usaha tidak akan berkembang. Sebab pondasi awal bisa berkembangnya sebuah usaha, kita harus memiliki ilmu pengetahuan atau keterampilan bidang yang ditekuni 


\section{Pembahasan}

\section{Pelaksanaan Pelatihan Massage di BRSPDSN Wyata Guna di masa Pandemi Covid-19}

Pelaksanan pelatihan massage di masa pandemic covid-19 walaupun pelaksanaannya terhalang dari segi praktek langsung yang diajarkan oleh instruktur kepada peserta pelatihan. Namun dengan adanya pandemic tidak membuat instruktur berhenti di situ saja untuk mengajarkan pelatihan kepada pesertanya. Seorang instruktur berusaha bahkan mensiasati pelatihan dengan menggunakan teleconference seperti aplikasi whatsapp, zello bahkan zoom. Akan tetapi jika instruktur hanya menggunakan media bahkan aplikasi untuk pelatihan tersebut dirasa tidak efektif karena kendala selalu ada dimasa pandemic ini bisa terlihat dari persoalan data dan signal. Data ini yaitu kuota karena jika menggunakan aplikasi tersebut banyak persoalan yang muncul, sehingga instruktur membuat terobosan baru seperti membuat channel youtube, dimana channel tersebut bisa dimanfaatkan untuk peserta pelatihan agar selalu melakukan pembelajaran mengenai pelatihan massage. Channel tersebut bermanfaat untuk peserta pelatihan, tidak hanya sebatas pesertanya tetapi masyarakat luas bisa mengakses videonya. Peserta pelatihan pun dari adanya channel tersebut lebih hemat dari segi kuota dimana peserta mengunduh terlebih dahulu sehingga bisa diulang terusmenerus. Pelatihan massage yang terkendala oleh pandemic covid-19, tidak menyurutkan langkah instruktur untuk bisa menyelesaikan materi-materi pelatihan. Untuk evaluasinya dilakukan menggunakan google forms, termasuk dalam pemberian penugasan kepada peserta pelatihan, bahkan di saat pandemic covid-19 diharapkan semua peserta pelatihan yang telah mendapatkan sertifikat atau piagam penghargaan atau semacamnya bisa melanjutkan keterampilan hidup yang ia dapatkan ketika pelatihan massage di masa pandemic covid-19.

Sewaktu adanya pandemic covid-19 keluarlah surat edaran dari kementrian social yang menyatakan kepada seluruh jajaran pegawai balai untuk menganjurkan memulangkan peserta pelatihan, pihak balai pun melaksanakan anjuran tersebut dengan berbagai pertimbangan, karena takutnya ada yang terdampak wabah covid-19. Pada awal pandemic masih melakukan pelatihan secara langsung, namun setelah merebahnya pandemic covid-19 peserta pelatihan dipulangkan kerumahnya dan pembelajarannya dilanjutkan secara online. Pembelajaran online menjadikan peserta pelatihan lebih aktif dan mencari tahu mengenai banyak hal, menurut (Firman \& Sari, 2020) pembelajaran online yaitu suatu kegiatan belajar yang memerlukan jaringan internet dengan konektivitas, fleksibilitas dan kemampuan untuk memunculkan berbagai macam interaksi di dalam kegiatan tersebut. Salah satu contohnya, yaitu dari penggunaan aplikasi yang digunakan saat pembelajaran bisa melalui whatsapp, zoom dan sebagainya.

Tetapi, peserta pelatihan tidak bisa setiap waktu mengikuti pembelajaran secara online dikarenakan keterbatasan kuota dan sebagainya. Dengan adanya pembelajaran online dirasa kurang efektif karena pelatihan massage yang seharusnya pembelajarannya lebih banyak praktek berkenaan dengan titik-titik urat saraf refleksi yang tidak bisa dilakukan secara daring, terlebih penyandang disabilitas tidak dapat melihat apa yang dicontohkan sehingga tidak bisa langsung mempraktekannya. Pembelajaran daring yaitu suatu sistem pembelajaran yang dilakukan dengan tidak bertatap muka secara langsung, tetapi menggunakan platform yang dapat membantu proses belajar mengajar yang dilakukan meskipun jarak jauh. Tujuan dari adanya pembelajaran daring adalah memberikan layanan pembelajaran yang bermutu dalam jaringan yang sifatnya kuat dan terbuka untuk menjangkau peminat ruang belajar agar lebih banyak serta luas (Sofyana \& Abdul, 2019). Apa pun bentuk pembelajarannya itu 
menjadi salah satu cara agar peserta pelatihan tetap belajar walaupun berada dirumahnya masing-masing.

Dan ada juga peserta pelatihan yang tidak bergegas untuk pulang dikarenakan peserta yang menggaris bawahi isi surat edaran tersebut yang mana di surat tersebut hanya menganjurkan bukan mengharuskan peserta pelatihan pulang, sehingga peserta pelatihan memutuskan untuk melanjutkan pelatihan. Kemudian mencoba menyampaikan aspirasinya kepada balai dan balai mempersilahkan peserta tetap melanjutkan pelatihan, karena aktivitas balai tetap berlangsung terlebih sebagian besar pegawai dan instruktur pelatihan tinggal dilingkungan komplek balai, sehingga anjuran-anjuran dari pemerintah untuk penanganan covid-19 dapat diterapkan.

\section{Implikasi dari Pelatihan Massage terhadap Keterampilan Hidup Tunanetra di Masa Pandemi Covid-19}

Bagi peserta pelatihan, dari adanya pelatihan massage di masa pandemic, keterampilan yang didapat membuat peserta pelatihan menjadi lebih mandiri. Peserta pelatihan bisa bekerja sesuai dengan keahlian yang telah dimiliki bahkan sertifikat yang telah ia dapatkan saat mengikuti pelatihan massage. Massage diambil dari Bahasa Francis, dalam bahasa Indonesia disebut pijat atau mengurut (lutut) (Nuraini, 2016). Massage sendiri mempunyai arti yaitu perawatan tubuh dengan menggunakan kedua tangan pada bagian telapak tangan maupun jari-jari tangan. Massage dapat memberikan manfaat berupa relaksasi, mengurangi nyeri, memperbaiki organ tubuh dan memelihara kebugaran, dengan pelatihan massage ini diyakini peredaran darah akan semakin lancar badan semakin relaks, tubuh semakin bugar dan berpengaruh pada peningkatan kesehatan (Junaidi, et al., 2017).

Dengan keahlian tersebut mereka bisa bekerja berdampingan dengan masyarakat seperti biasa. Hasil dari pelatihan ini, jika peserta pelatihan bersungguh-sungguh dalam belajar hasilnya pun akan di dapatkan kedepannya. Bisa diimplementasikan dimasyarakat, bahkan dari pelatihan tersebut menjadikan keahlian yang dapat dijadikan mata pencaharian untuk tunanetra sendiri.

Setelah mengikuti pelatihan tersebut pada dasarnya mengikuti pelatihan bukan karena tidak mempunyai pekerjaan tetapi ingin mengikuti pelatihan untuk menambah keterampilan hidupnya. Keterampilan hidup (life skills) yaitu pendidikan non-formal, yang berkaitan dengan keterampdfilan fisik, keterampilan mental, keterampilan emosional, keterampilan spiritual, keterampilan kejuruan dan keterampilan menghadapi kesulitan di kehidupan seharihari. Keterampilan hidup yang sering disebut juga kecakapan hidup yaitu berbagai keterampilan serta kemampuan yang dapat merubah seseorang untuk berperilaku positif dan beradaptasi dengan lingkungannya, yang memungkinkan seseorang bisa menghadapi berbagai tuntutan dan tantangan di kehidupan sehari-harinya secara efektif (BKKBN, 2012). Karena sebelum mengikuti pelatihan massage, sebagian kecil peserta sudah mempunyai usaha yang sudah dijalani, namun usaha yang telah dijalani perlu dikembangkan dengan cara membuka usaha dibidang yang lain seperti terapis yang bertujuan agar usaha yang dijalani tidak terfokus pada satu bidang, kemudian dapat membantu para tunanetra memberikan lapangan pekerjaan di bidang terapis. Paradigma tunanetra yang hanya bisa mengemis dan mengamen dijalanan dan adanya stigma masyarakat terhadap tunanetra bahwa tunanetra tidak memiliki keterampilan yang lain selain mengemis dan mengamen. Maka dari itu, peserta 
pelatihan berusaha mempelajari, memahami mengenai ilmu massage, sebelum memberikan lapangan pekerjaan dibidang terapis kepada tunanetra yang lain.

\section{KESIMPULAN}

Berdasarkan hasil penelitian kepada peserta pelatihan massage terhadap keterampilan hidup tunanetra di masa pandemic covid-19 disimpulkan sebagai berikut :

\section{Pelaksanaan Pelatihan Massage di BRSPDSN Wyata Guna di masa Pandemi Covid-19}

Walaupun terjadi pandemic covid-19 dimana segala aktivitas serba terbatas, tetapi tidak membuat balai menghentikan semua kegiatan pelatihan terutama pelatihan massage. Meskipun pelaksanaannya lebih mengandalkan pada teknologi seperti whatsapp, zello, zoom dan channel youtube. Akan tetapi secara hasil, pelaksanaanya tidak optimal karena antara teori dengan praktek harus selaras, sedangkan peserta pelatihan mengalami kesulitan baik dari penunjang pelatihan secara daring dan kesulitan mengaplikasikan teori yang telah dipelajari.

\section{Implikasi dari Pelatihan Massage terhadap Keterampilan Hidup Tunanetra di masa Pandemi Covid-19}

Dengan sistem pelatihan tersebut, peserta dituntut untuk lebih mandiri baik dari proses pelatihan maupun setelah selesai pelatihan, peserta dapat menerapkan keterampilan yang telah dimilikinya dijadikan sebagai mata pencaharian.

\section{PENGAKUAN}

Selama menyelesaikan penyusunan artikel ilmiah ini penulis telah banyak bantuan dan dukungan dari berbagai pihak. Untuk itu dengan segala kerendahan hati, penulis ingin menyampaikan ucapan terima kasih kepada semua pihak yang turut membantu, terutama orang tua yang selalu mendukung baik secara moril atau pun material, tak lupa terima kasih ibu, bapak editor dan ibu, bapak dosen pembimbing, khususnya Bapak Dinno Mulyono, M.Pd, selaku dosen pembimbing yang telah membantu, hingga penulisan artikel ilmiah ini dapat selesai tepat waktu.

\section{DAFTAR PUSTAKA}

Azzahro, A., \& Kurniadi, D. (2017). Penggunaan Tongkat pada Siswa Tunanetra SMALB dalam Melakukan Mobilitas. Jassi_anakku, Volume 18 No 1 Juni 2017, 19-25.

BKKBN. (2012). Pedoman Pengelolaan Bina Keluarga Remaja. Jakarta: Direktorat Bina Ketahanan Remaja.

Firman, \& Sari. (2020). Pembelajaran Online di Tengah Pandemi Covid-19.

Gitardiana, H. U., \& Namawi, A. (2017). Pelaksanaan Pelatihan Keterampilan Tata Cara Makan dan Minum bagi Anak Tunanetra dengan Disabilitas Tambahan (Studi Desktiptif Kualitatif pada Anak Tunanetra dengan Disabilitas Tambahan di PSBN Wyata Guna Kota Bandung). Jassi_anakku, Volume 18 No 1, 33-34.

Junaidi, S., Haniel, Y. N., Rizky , M. Y., Zamawi, M. A., Burstiando, R., Putra, R. P., . . . Weda, I. S. (2017). Pelatihan Massage Kebugaran Sebagai Untuk Menciptakan Peluang Usaha Bagi Remaja Karang Taruna Di Desa Ngulankulon Kabupaten Trenggalek. Jurnal ABDINUS, Volume 1 No 1, 41. 
22 Mulyani, S., Implikasi Pelatihan Massage Terhadap Keterampilan Hidup Tunanetra Di Masa Pandemi Covid-19

Mustofa, A. (2019, Desember 2019). Dilema 21,5 Juta Penyandang Difabel di Indonesia. Retrieved Agustus 18, 2020, from radarbali.jawapos.com: https://radarbali.jawapos.com/read/2019/12/07/169177/dilema-215-juta-penyandangdifabel-di-indonesia

Nuraini, S. (2016). Pelatihan Massage Bagi Eks Tenaga Kerja Indonesia Di Subang Jawa Barat. Jurnal Sarwihata, Volume 13 No. 1, 28.

Silalahi, U. (2009). Metode Penelitian Sosial. Bandung: PT. Refika Aditama.

Sofyana, \& Abdul. (2019). Pembelajaran Daring Kombinasi Berbasis Whatsapp Pada Kelas Karyawan Prodi Teknik Informatika Universitas PGRI Madiun. Jurnal Nasional Pendidikan Teknik Informatika, Volume 8 Nomor 1, 82.

Somantri, T. S. (2007). Psikolog Anak Luar Biasa. Bandung: Refka Aditama.

Sugiyono. (2018). Metode Penelitian Kuantitatif, Kualitatif, dan R\&D. Bandung: Alfabeta, ,cv.

Widodo, S. E. (2015). Manajemen Pengembangan Sumber Daya Manusia. Yogyakarta: Pustaka Belajar. 